\title{
UPAYA PENANGGULANGAN ILLEGAL, UNREPORTED AND UNREGULETED FISHING DI ZONA EKONOMI EKSKLUSIF INDONESIA
}

\section{ILLEGAL, UNREPORTED AND UNREGULETED FISHING TREATMENT EFFORTS IN INDONESIA'S EXCLUSIVE ECONOMIC ZONE}

\author{
Elsa Aprina ${ }^{1}$, Mukhammad Rosyid Ridho ${ }^{2}$ \\ Fakultas Hukum Universitas Balikpapan ${ }^{12}$ \\ Jalan Pupuk Kelurahan Gunung Bahagia \\ Email : elsafhuniba@gmail.com,07.ridho@gmail.com
}

\begin{abstract}
ABSTRAK
Penelitian ini dilatarbelakangi dari adanya tindakan Illegal, Unreported, and Unregulated (IUU) Fishing yang dilakukan oleh kapal asing penangkap ikan dari Republik Rakyat Tiongkok di Zona Ekonomi Eksklusif Indonesia. Permasalahan yang akan dikaji dalam penelitian ini adalah bagaimanakah upaya penanggulangan tindakan Illegal, Unreported, and Unregulated (IUU) Fishing yang dilakukan oleh kapal asing penangkap ikan asing di Zona Ekonomi Eksklusif Indonesia, serta langkah-langkah yang dapat dilakukan oleh Pemerintah Republik Indonesia untuk melindungi Zona Ekonomi Eksklusif yang dimilikinya dari tindakan Illegal, Unreported, and Unregulated (IUU) Fishing. Metode yang digunakan oleh penulis dalam penelitian ini adalah yuridis normatif. Adapun hasil penelitian menunjukan bahwa upaya penanggulangan IUU Fishing dapat dilakukan melalui cara penaatan terhadap hukum dan melaksanakan penegakan hukum. Bahwa Pemerintah Republik Indonesia perlu meningkatkan koordinasi patroli antar penegak hukum di wilayah di laut, memberdayakan nelayan lokal untuk meningkatkan intensifikasi nelayan Republik Indonesia di Zona Ekonomi Eksklusif, membentuk Coast Guard Unit, dan segera menyelesaikan perjanjian batas wilayah laut di Zona Ekonomi Eksklusif dalam rangka melindungi Zona Ekonomi Eksklusif Indonesia dari tindakan Illegal, Unreported, and Unregulated (IUU) Fishing.
\end{abstract}

Kata Kunci : Zona Ekonomi Eksklusif; Illegal, Unreported, and Unregulated (IUU) Fishing; Indonesia

\begin{abstract}
This research is motivated by the illegal, unreported, and unregulated (IUU) fishing conducted by foreign fishing vessels from the People's Republic of China in Indonesia's Exclusive Economic Zone. The problems that will be examined in this study are how efforts to combat illegal, unreported, and unregulated (IUU) fishing actions carried out by foreign fishing vessels in Indonesia's Exclusive Economic Zone, as well as measures that can be taken by the Government of the Republic of Indonesia to protect its Exclusive Economic Zone from illegal, unreported, and unregulated (IUU) fishing. The method used by the authors in this study is normative juridical. The results showed that efforts to combat IUU Fishing can be done through law enforcement and law enforcement. That the Government of the Republic of Indonesia needs to improve coordination of patrols between law
\end{abstract}


enforcement in the region at sea, empower local fishermen to increase the intensification of Indonesian fishermen in the Exclusive Economic Zone, establish a Coast Guard Unit, and immediately finalize the sea boundary agreement in the Exclusive Economic Zone in order to protect Indonesia's Exclusive Economic Zone from illegal, unreported, and unregulated (IUU) fishing.

Keywords : Exclusive Economic Zones; illegal, unreported, and unregulated (IUU) fishing; Indonesia.

\section{PENDAHULUAN}

\section{A. Latar Belakang}

Salah satu sumber dari pendapatan negara adalah berasal dari kekayaan yang berada di wilayah laut. Baik itu kekayaan laut yang hayati maupun kekayaan laut yang non hayati. Indonsia yang notabene merupakan negara yang memiliki garis pantai terpanjang nomor dua setelah Negara Kanada dengan panjang 99.093 kilometer. ${ }^{1}$ Dengan predikat negara nomor dua pemilik pantai terpanjang, tentu saja membuat Indonesia menjadi negara yang kaya dengan hasil panen dari wilayah laut. Selain itu pula, Indonesia menjadi salah satu negara yang dapat mengklaim semua zonasi laut yang telah ditentukan oleh Konvensi Hukum Laut 1982 atau yang dikenal dengan United Nations Convention the Law of The Sea 1982. Mulai dari wilayah perairan laut territorial, zona tambahan, landas kontinen dan zona ekonomi eksklusif.

Dikenal sebagai negara yang memiliki wilayah laut yang luas, tentu banyak tantangan yang dihadapi oleh pemerintah untuk menjaga wilayah lautnya dari kegiatankegiatan yang illegal. Potensi sengketa di wilayah laut tentu akan lebih tinggi dibandingkan dengan negara-negara yang garis pantainya sempit.

Diketahui bahwa pada 19 Desember 2019, sejumlah kapal asing penangkap ikan yang berasal dari Republik Rakyat Tiongkok diketahui memasuki Perairan Natuna Utara, Kepulauan Riau. Setelah dikonfirmasi sejumlah kapal penangkap ikan asing yang berasal dari Republik Rakyat Tiongkok tersebut telah melanggar wilayah Zona Ekonomi Eksklusif yang dimiliki Republik Indonesia dan melakukan kegiatan Illegal, Unreported, and Unregulated (IUU) Fishing. Saat Badan Keamanan Laut (BAKAMLA) melakukan upaya pengusiran, upaya tersebut dihalangi oleh China Coast Guard (CCG). ${ }^{2}$

Pemerintah Republik Indonesia berdasarkan ketentuan yang telah diatur dalam UNCLOS 1982 memiliki hak berdaulat di Perairan Natuna Utara, Kepulauan Riau. Tindakan yang dilakukan oleh kapal asing penangkap ikan dari Republik Rakyat Tiongkok serta China Coast Guard (CCG) telah melanggar hak berdaulat yang dimiliki

\footnotetext{
${ }^{1}$ Garis pantai Indonesia terpanjang kedua di dunia, diakses melalui https://www.antaranews.com/berita/487732/garis-pantai-indonesia-terpanjang-kedua-di-dunia, pada September 2020

${ }^{2}$ Kompas Cyber Media, "Masuknya Kapal China Ke Perairan Natuna Yang Diprotes Indonesia... Halaman All," Kompas.Com, Accessed January $\quad$ 4, 2020 , Https:/Www.Kompas.Com/Tren/Read/2019/12/31/164819565/Masuknya-Kapal-China-Ke-Perairan-NatunaYang-Diprotes-Indonesia.
} 
oleh Republik Indonesia. Berdasarkan Pasal 73 UNCLOS 1982 Pemerintah Republik Indonesia seharusnya dapat melakukan upaya penegakan hukum sesuai dengan ketentuan peraturan perundang-undangan nasional. Oleh karena itu dalam penulisan ini penulis tertarik untuk mengkaji lebih lanjut mengenai bagaimana upaya penanggulangan IUU Fishing yang dapat dilakukan Pemerintah Republik Indonesia terhadap kapal asing penangkap ikan dari Republik Rakyat Tiongkok di Zona Ekonomi Eksklusif Indonesia.

Sebelumnya telah ada tulisan yang serupa dengan apa yang menjadi penelitian penulis diantaranya: Perlindungan Hukum Zona Ekonomi Eksklusif (ZEE) Terhadap Eksistensi Indonesia Sebagai Negara Maritim yang ditulis oleh Aditya Taufan Nugraha dan Imran yang terfokus pada penegakan hukum di ZEEI, sedangkan penulisan karya ilmiah ini mencoba menjelaskan tidak hanya berkaitan dengan penegakan hukum tapi berkaitan pula dengan upaya penanggulangan IUU Fishing di Zona Ekonomi Eksklusif Indonesia. Begitu pula dengan artikel ilmiah yang berjudul Penegakan Hukum Laut Di Indonesia yang ditulis oleh Eka Martiana Wulansari yang fokus membahas tentang penegakan hukum di wilayah laut Indonesia. Adapun kedua artikel ilmiah tersebut kemudian menjadi rujukan penulis dalam penulisan ini.

\section{B. Rumusan Masalah}

Berdasarkan latar belakang yang penulis sampaikan di atas, maka perumusan masalah dalam penelitian ini yaitu Bagaimanakah upaya penaggulangan IUU Fishing yang dapat dilakukan oleh pemerintah Indonesia untuk melindungi Zona Ekonomi Eksklusif nya dari Kapal Penangkap Ikan Asing.

\section{Metode}

Metode penelitian yang digunakan dalam menulis jurnal adalah menggunakan metode penelitian Yuridis Normatif. Dalam metode penelitian yuridis normatif pendekatan yang digunakan adalah pendekatan kepustakaan. ${ }^{3}$ Sumber hukum yang digunakan dalam penentuannya terbagi 2 yaitu sumber hukum primer dan sumber hukum sekunder. Sumber hukum primer ini menggunakan Perjanjianperjanjian Internasional dan Peraturan-peraturan Perundang-undangan hukum Nasional yang terkait dengan wilayah laut. Sedangkan sumber hukum sekunder yang digunakan adalah berasal dari buku-buku, jurnal, skripsi, ataupun tesis tentang yang berkaitan dengan sengketa di Zona Ekonomi Eksklusif. ${ }^{4}$

\section{Tinjauan Pustaka}

\section{Zona Ekonomi Eksklusif}

\footnotetext{
${ }^{3}$ J. Supranto, Metode Penelitian Hukum Dan Statistik, Pertama (Jakarta: Rineka Cipta, 2003), Hlm. 2.

${ }^{4}$ Peter Mahmud Marzuki, Penelitian Hukum, Pertama (Jakarta: Kencana Prenada Media Group, 2009), Hlm. 141.
} 
Zona Ekonomi Eksklusif merupakan hak berdaulat suatu Negara Pantai (Coastal State) yang terbatas atau secara tidak penuh dalam penguasaannya. ${ }^{5}$ Zona Ekonomi Eksklusif adalah salah satu dari diberlakukannya Perjanjian Internasional UNCLOS 1982 sebagai implementasi dari Bab 5 UNCLOS 1982. Zona ekonomi eksklusif adalah suatu daerah di luar dan berdampingan dengan laut teritorial, yang tunduk pada rejim hukum khusus dimana didalam Zona Ekonomi Eksklusif terdapat hak-hak berdaulat dan yurisdiksi negara pantai dan hak-hak serta kebebasan-kebebasan negara lain. ${ }^{6}$ Batas wilayah Zona ekonomi eksklusif tidak boleh melebihi 200 mil laut dari garis pangkal darimana lebar laut teritorial diukur. $^{7}$

Sebelum disahkannya UNCLOS 1982 Negara Pantai (Coastal State) hanya memiliki Kedaulatan atas wilayah laut seluas 3 mil laut. Perkembangan teknologi pada negara-negara maju membuat negara-negara tersebut mempunyai kemampuan melakukan eksplorasi dan eksplorasi sumber daya alam hingga laut bebas. Meningkatnya kemampuan teknologi dalam melakukan eksplorasi dan eksplorasi sumber daya alam di laut ini menjadi pemicu Negara Pantai (Coastal State) melakukan deklarasi atas klaim wilayah laut yang lebih luas.

Konsep Zona Ekonomi Eksklusif pertama diperkenalkan Presiden Amerika Serikat Harry S. Truman pada 28 September 1945 melalui Truman Proclamation. Pada proklamasi pertama Harry S. Truman menjelaskan perlunya kontol atas konsevasi dan kehati-hatian dalam pemanfaatan sumber daya alam, pada sumber daya di dasar laut yang berada di Zona Ekonomi Eksklusif yang berdekatan dengan pantai Amerika Serikat oleh Pemerintah Amerika Serikat termasuk dalam sumber daya perikanan diatasnya.

Perkembangan selanjutnya yaitu Santiago Declaration yang ditandatangani oleh 3 negara yaitu : Chili, Ekuador, Peru pada 18 Agustus 1952. Dalam Santiago Declaration menyatakkan prinsip bahwa Negara Pantai (Coastal State) memiliki yurisdiksi atas wilayah laut seluas 200 mil laut pantainya, termasuk dasar laut dan tanah diatasnya. Setelah itu banyak negara-negara yang menerapkan rezim Zona Ekonomi Eksklusif sehingga pada tahun 1970 Majelis Umum PBB mengeluarkan Resolusi No.2750 (XV) yang memberikan mandat kepada Committe on the Peaceful Uses of the Sea-Bed and the Ocean Floor beyond the Limits of National Jurisdiction. Hingga sebelum disepakatinya UNCLOS 1982 pada Januari tahun 1971 Kenya megajukan proposal kepada Asian-Africa Legal Consultative Committee, serta dengan proposal yang sama mengajukan kepada United Nations Sea-bed Committe. Dalam pertemuan tersebut mengakui luas wilayah laut teritorial seluas 12 mil laut, dan sepakat menganggap Zona Ekonomi Eksklusif dapat

5 Cornelis Djelfie Massie, Pengantar Hukum Kawasan Perbatasan Dan Pulau-Pulau Terluar Indonesia Perspektif Hukum Laut Internasional, I (Pustaka Referensi, 2019), Hlm. 25.

${ }^{6}$ Unclos And Agreement On Part Xi - Preamble And Frame Index, Pasal 55.

${ }^{7}$ Unclos And Agreement On Part Xi - Preamble And Frame Index, Pasal 57. 
memberikan kompensasi kepada negara-negara berkembang karena belum mampu melakukan eksplorasi dan eksploitasi hingga laut bebas. ${ }^{8}$

\section{a. Hak dan Kewajiban di Zona Ekonomi Eksklusif}

Hak berdaulat pada Zona Ekonomi Eksklusif diperuntukan keperluan eksplorasi dan eksploitasi, konservasi dan pengelolaan sumber kekayaan alam, baik hayati maupun non-hayati di zona tersebut. Batasan-batasan atas yurisdiksi pada zona ini adalah : ${ }^{9}$

i. Pembuatan dan pengelolaan pulau buatan dan instalasi bangunan.

ii. Riset ilmiah kelautan

iii. Perlindungan dan pelestarian lingkungan laut

Yurisdiksi di Zona Ekonomi Eksklusif terbatas pada hak untuk melakukan eksploitasi sumber kekayaan alam yang terkandung dalam wilayah yang luasnya sebatas 200 mil laut dari titik garis pangkal yang dimiliki Negara Pantai (Coastal State), dengan tetap mengakui adanya status lain dari perairan tersebut sebagai laut bebas. Dengan perkataan lain, yurisdiksi yang diberikan oleh konvensi hanya terbatas pada hak-hak ekonomi negara pantai atas kekayaan alamnya. Sedangkan di bidang pelayaran dan pemasangan kabel dan pipa di bawah laut, tetap merupakan laut bebas. Maka hak-hak berdaulat ini tidak menjadikan Negara Pantai (Coastal State) memiliki kedaulatan penuh, namun hak-hak berdaulat ini tetap memberikan keuntungan ekonomis bagi Negara Pantai (Coastal State).

Dalam pembuatan dan pengelolaan pulau buatan dan instalasi bangunan Negara Pantai (Coastal State) berkewajiban mengumumkan pemberitahuan adanya instalasi dan pulau buatan. Pengumuman tersebut meliputi kedalaman, posisi dan dimensi setiap instalasi atau bangunan yang tidak dibongkar secara keseluruhan. Negara Pantai (Coastal State) wajib melakukan pembongkaran atas instalasi dan pulau buatan telah ditinggalkan atau tidak terpakai. Apabila diperlukan, Negara Pantai (Coastal State) dapat menetapkan zona keselamatan yang pantas di sekeliling instalasi dan pulau buatan dengan jarak tidak boleh melebihi 500 meter sekeliling bangunan tersebut. ${ }^{10}$

Negara Pantai (Coastal State) dapat menetapkan Peraturan Perundangundangan di Zona Ekonomi Eksklusif dalam upaya mengimplementasikan hak berdaulat dimilikinya secara optimal. ${ }^{11}$ Agar terjaminnya ketaatan pada Peraturan Perundang-undangan yang telah ditetapkan, Negara Pantai (Coastal

\footnotetext{
${ }^{8}$ Dhiana Puspitawati, Hukum Laut Internasional, Pertama (Depok: Kencana, 2017), Hlm. 66-71.

${ }^{9}$ Unclos And Agreement On Part Xi - Preamble And Frame Index, Pasal 56.

${ }^{10}$ Unclos And Agreement On Part Xi - Preamble And Frame Index, Pasal 60.

11 Joko Sulistyanto, "Implementasi Konvensi Hukum Laut Internasional 1982 Dalam Pembaharuan UndangUndang Perikanan,” Jurnal Lex Librum 1, No. Nomor 1 (December 8, 2014): Hlm. 38, Https://Doi.Org/10.5281/Zenodo.1256373.
} 
State) dapat melakukan upaya Penegakan Hukum menurut ketentuan Pasal 73 UNCLOS 1982 yang diantaranya yaitu $:^{12}$

1. Negara pantai (Coastal State) dalam melaksanakan hak berdaulatnya untuk melakukan eksplorasi, eksploitasi, konservasi dan pengelolaan sumber kekayaan hayati di zona ekonomi eksklusif mengambil tindakan demikian, termasuk menaiki kapal, memeriksa, menangkap dan melakukan proses peradilan, sebagaimana diperlukan untuk menjamin ditaatinya peraturan perundang-undangan yang ditetapkannya sesuai dengan ketentuan UNCLOS 1982

2. Kapal-kapal yang ditangkap dan awak kapalnya harus segera dibebaskan setelah diberikan suatu uang jaminan yang layak atau bentuk jaminan lainnya.

3. Hukuman Negara pantai yang dijatuhkan terhadap pelanggaran peraturan perundang-undangan perikanan di zona ekonomi eksklusif tidak boleh mencakup pengurungan, jika tidak ada perjanjian sebaliknya antara Negara-negara yang bersangkutan, atau setiap bentuk hukuman badan lainnya.

4. Dalam hal penangkapan atau penahanan kapal asing Negara pantai harus segera memberitahukan kepada Negara bendera, melalui saluran yang tepat, mengenai tindakan yang diambil dan mengenai setiap hukuman yang kemudian dijatuhkan.

\section{b. Zona Ekonomi Eksklusif Indonesia}

Zona Ekonomi Eksklusif Indonesia adalah wilayah hak berdaulat yang dimiliki oleh Republik Indonesia. Letak Zona Ekonomi Eksklusif Indonesia berada sepanjang jalur di luar dan berbatasan dengan laut wilayah Indonesia dengan batas ukur terluar 200 (dua ratus) mil laut diukur dari garis pangkal laut wilayah Indonesia. ${ }^{13}$ Setiap kegiatan meliputi eksplorasi dan eksploitasi sumber daya alam, pemanfaatan instalasi dan pulau-pulau buatan, serta melakukan kegiatan penelitian di Zona Ekonomi Eksklusif Indonesia harus berdasarkan izin dari Pemerintah Republik Indonesia atau berdasarkan persetujuan internasional dengan Pemerintah Republik Indonesia dan dilaksanakan menurut syarat-syarat perizinan atau persetujuan internasional tersebut.

\section{Illegal, Unreported, and Unregulated (IUU) Fishing.}

Illegal, Unreported, and Unregulated (IUU) Fishing_adalah tindakan ilegal, tidak terlapor, dan tidak diatur dalam bidang perikanan. Secara harfiah berdasarkan batasan yang diberikan Pengawasan Sumber Daya Kelautan dan Perikanan Kementrian Kelautan dan Perikanan, Illegal, Unreported, and Unregulated (IUU)

\footnotetext{
${ }^{12}$ Unclos And Agreement On Part Xi - Preamble And Frame Index, Pasal 73.

${ }^{13}$ Pasal 2 "Undang-Aundang Nomor 5 Tahun 1983 Tentang Zona Ekonomi Eksklusif Indonesia," Accessed October 21, 2020, Http://Www.Dpr.Go.Id/Jdih/Index/Id/781.
} 
Fishing dapat diartikan sebagai kegiatan perikanan yang tidak sah, kegiatan perikanan yang tidak diatur oleh peraturan yang ada, atau aktivitasnya tidak dilaporkan kepada suatu institusi atau lembaga pengelola perikanan yang tersedia.

Berdasarkan informasi yang telah dilansir dari website Food Agriculture Organization $(F O A)^{14}$ Illegal, Unreported, and Unregulated (IUU) Fishing merupakan ancaman terbesar bagi perkembangan ekosistem di wilayah laut. Selain itu pula, Illegal, Unreported, and Unregulated (IUU) Fishing mampu mengganggu upaya nasional ataupun regional dalam pengelolaan perikanan secara berkelanjutan serta upaya untuk melestarikan keanekaragaman hayati laut. Tindakan ini mengambil keuntungan dari administrasi yang tidak sesuai, dan Eksploitasi Management suatu Rezim yang lemah terutama Negara-negara berkembang yang kurang memiliki kapasitas dalam pemantauan, kontrol, dan pengawasan. Karena terjadi di semua mensi, di laut lepas maupun di yurisdiksi Nasional tindakan ini termasuk dalam kejahatan transnasional dan terorganisir. Keberadaan Illegal, Unreported, and Unregulated (IUU) Fishing telah mengancam sumber daya perikanan bagi nelayan-nelayan di suatu negara berkembang. Selain itu pula para pelaku Illegal, Unreported, and Unregulated (IUU) Fishing dapat menemukan jalan ke pasar perdagangan luar negeri sehingga menghambat pasokan makanan nasional.

Illegal Fishing termasuk kegiatan malpraktek dalam memanfaatkan sumber daya perikanan dan merupakan kegiatan pelanggaran hukum. Tindakan Illegal Fishing adalah penggunaan alat tangkap yang dapat merusak ekosistem seperti penggunaan bom, racun, dan penggunaan alat tangkap trawl dalam daerah terumbu karang. Menurut International North Pasific Fisheries Comission (INPC) tindakan Illegal Fishing dapat dikatakan sebagai berikut :

a. Tanpa ijin dari pemerintahan suatu negara

b. Memalsukan serta menggandakan buku laporan perikanan

c. Tidak melaporkan nama, jumlah, dan posisi kapal

d. Menyiksa petugas pengawas

e. Menangkap ikan tanpa ijin di wilayah ZEE negara lain

f. Melanggar ketentuan perjanjian internasional dan kebiasaan internasional

g. Memindahkan tangkapan ke kapal lain di tengah laut agar tidak dapat diidentifikasi

h. Mengganti bendera untuk menghindari kewajiban-kewajiban dalam perjanjian dengan negara lain

\section{PEMBAHASAN}

A. Hak Berdaulat Pemerintah Republik Indonesia di Laut Natuna Utara

14 "Illegal, Unreported And Unregulated (Iuu) Fishing|Food And Agriculture Organization Of The United Nations," Accessed February 1, 2020, Http://Www.Fao.Org/Iuu-Fishing/En/. 
Sebagaimana telah di tentukan dalam Konvensi Hukum Laut, bahwa setiap negara pantai berhak untuk menetapkan ZEE nya sejauh 200 mil laut. Sehingga atas dasar ketentuan tersebut Negara Republik Indonesia memiliki hak untuk mengelola wilayah laut sejauh 200 mil laut di wilayah perairannya. Wilayah perairan 200 mil laut ini merupakan wilayah perikanan Negara Indonesia yang memiliki status hukum hak berdaulat. Hak Berdaulat atas Zona Ekonomi Eklsklusif tersebut berbatasan dengan Negara Vietnam dan Malaysia. Hak Berdaulat atas Zona Ekonomi Eklsklusif yang diberikan UNCLOS 1982 kepada Republik Indonesia meliputi kegiatan eksplorasi, eksploitasi dan Konservasi Sumber Daya Alam. Dalam mengimplementasikan Hak Berdaulat atas Zona Ekonomi Eklsklusif, Republik Indonesia dapat menetapkan Peraturan Perundang-undangan wilayah Zona Ekonomi Eklsklusif yang dimiliki Republik Indonesia. Agar terjaminnya kepatuhan terhadap Peraturan Perundang-undangan wilayah Zona Ekonomi Eklsklusif yang dimiliki Republik Indonesia, UNCLOS 1982 memberikan kesempatan kepada Republik Indonesia sebagai negara pantai yang memiliki Hak Berdaulat atas Zona Ekonomi Eklsklusif untuk melaksanakan kewenangannya sesuai dengan Konvensi termasuk menjaga wilayah perikanannya dari tindakan yang mengancam sumber daya perikanan di wilayah tersebut.

Laut Natuna yang masuk ke dalam bagian Laut China Selatan merupakan wilayah perairan Indonesia yang berpolemik dengan RRT, dimana RRT mengklaim secara sepihak wilayah perairan ini menjadi milik negaranya. Padahal alasan yang menjadi dasar argument RRT tidak memiliki dasar hukum yang kuat, dikarenakan klaim yang digunakan RRT bertentangan dengan UNCLOS 1982. ${ }^{15}$ Berbeda dengan dasar hukum klaim yang digunakan oleh Negara Indonesia dalam pengelolaan wilayah Laut Natuna yang lebih jelas yakni klaim Negara Indonesia didasarkan pada ketentuan Konvensi Hukum Laut 1982. Atas keyakinan RRT yang melakukan klaim secara sepihak inilah mengakibatkan seringkali kapal penangkap ikan asing RRT berada di wilayah Laut Natuna.

Selain itu, dapat dilihat pula bahwa RRT tidak memiliki hak apapun di Laut Natuna berdasarkan pada putusan Permanet Court of Arbitration (PCA) tanggal 12 Juli 2016, atas gugatan Filipina melawan Republik Rakyat Tiongkok terkait masalah Laut Cina Selatan (LCS). Dalam Press Realease terkait dengan putusan yang dikeluarkan oleh Permanet Court of Arbitration (PCA) mengenai klaim atas Hak Sejarah (Historic Rights) dan Sembilan Garis Putus-putus (Nine Dash Line) di Laut Cina Selatan (LCS), Permanet Court of Arbitration (PCA) menjelaskan bahwa : ${ }^{16}$

\footnotetext{
${ }^{15}$ Ana Fatmawati, Elsa Aprina, Keabsahan Alasan Penolakan Republik Rakyat Tiongkok Terhadap Putusan Permanent Court Arbitration Atas Sengketa Klaim Wilayah Laut China Selatan Antara Filipina dan Republik Rakyat Tiongkok, Jurnal Varietas Justisia Volume 5 Nomor 1, Hal. 109, diakses pada 15, November 2020

${ }^{16}$ PCA Press Release: The South China Sea Arbitration (The Republic Of The Philippines V. The People's Republic Of China) | Pca-Cpa, Accessed November 15, 2020.
} 
"The Tribunal concluded that, to the extent China had historic rights to resources in the waters of the South China Sea, such rights were extinguished to the extent they were incompatible with the exclusive economic zones provided for in the Convention. The Tribunal also noted that, although 2 Chinese navigators and fishermen, as well as those of other States, had historically made use of the islands in the South China Sea, there was no evidence that China had historically exercised exclusive control over the waters or their resources. The Tribunal concluded that there was no legal basis for China to claim historic rights to resources within the sea areas falling within the 'nine-dash line'.",

Jelaslah dalam putusan PCA yang tidak memberikan pengakuan kepada alas klaim yang diajukan oleh Republik Rakyat Tiongkok, sehingga RRT memang tidak sah dalam hal kepemilikan wilayah laut di LCS, terkhusus di Laut Natuna Utara. Meskipun RRT memberikan penyataan tidak menerima dan tidak akan mengakui putusan dari Permanet Court of Arbitration (PCA) tersebut. Walapun demikian putusan dari Permanet Court of Arbitration (PCA) tersebut bersifat final dan mengikat. Sehingga sudah seharusnya sebagai bentuk itikad baik terhadap Perjanjian Internasional Republik Rakyat Tiongkok yang juga bagian dari masyarakat internasional untuk mematuhi putusan dari Permanet Court of Arbitration (PCA) tersebut. ${ }^{17}$

\section{B. Memahami Bahwa Kedudukan Yang Sama Antara Republik Indonesia dan} Republik Rakyat Tiongkok Sebagai Negara Peratifikasi UNCLOS 1982

UNCLOS 1982 adalah Perjanjian Internasional yang dihasilkan dari Konferensi Perserikatan Bangsa-Bangsa tentang Hukum Laut yang ketiga kalinya dan berlangsung mulai dari tahun 1973 sampai tahun 1982. UNCLOS 1982 diberlakukan pada tahun 1994, setahun setelah Guyana menjadi negara ke 60 yang meratifikasi perjanjian tersebut. UNCLOS 1982 telah diratifikasi oleh sekitar 168 Negara Pihak. Republik Indonesia dan Republik Rakyat Tiongkok termasuk dalam Negara Pihak yang meratifikasi Konvensi tersebut.

Republik Indonesia menandatangani UNCLOS 1982 pada tanggal 10 Desember 1982 dan meratifikasi UNCLOS 1982 pada tanggal 31 Desember 1985, sesuai dengan ketentuan "Undang-undang Nomor 17 Tahun 1985 Tentang Pengesahan United Nations Convention on the Law of the Sea (Konvensi Perserikatan Bangsa-bangsa Tentang Hukum Laut)". Sedangkan Republik Rakyat Tiongkok Indonesia menandatangani UNCLOS 1982 pada tanggal 10 Desember 1982 dan meratifikasi UNCLOS 1982 pada tanggal 15 Mei $1996 .^{18}$

Upaya penetapan UNCLOS 1982 sebagai Hukum Laut Internasional bertujuan untuk memberikan kontribusi terwujudnya tatanan ekonomi internasional yang adil

\footnotetext{
17 Op.Cit., Darajati, Adolf, And Idris, "Putusan Sengketa Laut China Selatan Serta Implikasi Hukumnya Terhadap Negara Di Sekitar Kawasan Tersebut,” Hlm. 38-39.

18 Zheng Wang, "China And Unclos: An Inconvenient History," Accessed November 12, 2020, Https://Thediplomat.Com/2016/07/China-And-Unclos-An-Inconvenient-History/.
} 
dan merata, memperhitungkan kepentingan dan kebutuhan umat manusia secara keseluruhan, dan dalam khususnya kepentingan dan kebutuhan khusus negara berkembang. Upaya penetapan UNCLOS 1982 didasari kebutuhan Perjanjian Internasional yang tetap memperhatikan kedaulatan semua Negara, tatanan hukum untuk laut dan lautan yang akan memfasilitasi komunikasi internasional, mempromosikan pemanfaatan laut dan samudera secara damai, pemanfaatan yang adil dan efisien sumber daya, konservasi sumber daya hidup, dan studi perlindungan dan pelestarian lingkungan laut. ${ }^{19}$ Maka Republik Indonesia dan Republik Rakyat Tiongkok sebagai Negara yang Meratifikasi UNCLOS 1982 berkewajiban menghormati ketentuan-ketentuan, dan Kedaulatan serta Hak Berdaulat yang dimiliki masing-masing Negara.

C. Upaya Penanggulangan Tindakan Illegal, Unreported, and Unregulated (IUU) Fishing di Zona Ekonomi Eksklusif Indonesia Dari Kapal Penangkap Ikan Asing

Adapun upaya penanggulangan IUU fishing di Indonesia dapat dilakukan melalui dua cara yakni kepatuhan terhadap aturan atau hukum yang berlaku (compliance) dan penegakan hukum (enforcement) yang tegas oleh penegak hukum suatu negara. Kepatuhan terhadap hukum dilakukan sebagai upaya preventif melalui pengimplementasian perjanjian-perjanjian internasional kedalam hukum nasional, penataan hukum, peningkatan sarana dan prasarana perikanan, serta sistem pemantauan, pengendalian dan pengawasan untuk menjamin bahwa peraturan perundang-undangan yang ada ditaati dan dilaksanakan. Penegakan hukum sebenarnya merupakan bagian dari kepatuhan terhadap hukum, tetapi secara prakteknya dibedakan karena penegakan hukum merupakan upaya represif yang dilakukan setelah terjadinya ketidaktaatan hukum (non-compliance) yang memberikan sanksi-sanksi sesuai dengan isi peraturan perundang-undang.

Dilihat dari segi peraturan hukum internasional, upaya pentaatan hukum yang dilakukan oleh Indonesia adalah dengan mengadopsi ketentuan hukum internasional untuk dapat diterapakan kedalam hukum nasional. Dalam upaya konservasi dan pengelolaan perikanan, Indonesia telah meratifikasi UNCLOS 1982 melalui UndangUndang No.17 tahun 1985 tentang Pengesahan United Nations Convention on the Law of the Sea (Konvensi Perserikatan Bangsa-Bangsa tentang Hukum Laut, serta mengadopsi beberapa ketentuan-ketentuan code of conduct for responsible fisheries yang dituangkan dalam Undang-Undang Nomor 31 tahun 2004 tentang Perikanan yang kini telah diganti dengan Undang-Undang Nomor 45 Tahun 2009 Tentan Perikanan.

Jika dilihat dari segi kepatuhan terhadap hukum nasional telah dilakukan melalui penataan hukum nasional yakni dengan pembuatan beberapa peraturan perundang-undangan yang sesuai dengan kondisi saat ini. Indonesia telah mempunyai peraturan perikanan yang telah diperbaharui yakni Undang-Undang 45 Tahun 2009

${ }^{19}$ Unclos And Agreement On Part Xi - Preamble And Frame Index, Hlm. 25. 
Tentang Perubahan Atas Undang-undang 31 Tahun 2004 Tentang Perikanan. Selain itu, ketentuan dalam Undang Undang No.5 tahun 1985 tentang ZEE Indonesia dan PP No.15 tahun 1984 tentang Pengelolaan Sumberdaya Alam Hayati di ZEEI masih tetap berlaku. Kemudian, tidak hanya pentaatan hukum melalui peraturan perundangundangan, namun juga harus dilakukan melalui praktik diantaranya;

1. Registrasi merupakan hal pertama yang harus dilakukan oleh kapal-kapal perikanan yang akan menjadi kapal perikanan Indonesia yang akan dioperasikan di wilayah pengelolaan perikanan Indonesia. ${ }^{20}$ Mengenai pengukuran, pendaftaran dan tanda kebangsaan kapal diperoleh dari Departemen Perhubungan berdasarkan Undang-Undang Nomor 17 tahun 2008 tentang Pelayaran.

2. Penertiban pemberian izin. Berdasarkan Undang-Undang Nomor 45 tahun 2009 tentang Perikanan mengatur mengenai pemberian izin penangkapan ikan, dimana Pasal 26 ayat (1) menyatakan bahwa setiap orang yang melakukan usaha perikanan, termasuk di bidang penangkapan dan pengangkutan ikan di wilayah pengelolaan perikanan Republik Indonesia wajib memiliki Surat Izin Usaha Perikanan (SIUP), ${ }^{21}$ kecuali bagi nelayan-nelayan kecil. ${ }^{22}$

3. Pelatihan, pendidikan, dan penyuluhan perikanan sebagai salah satu bentuk sosialisasi perikanan dapat dianggap sebagai salah cara pentaatan hukum di bidang perikanan. Keuntungan yang didapatkan dari kegiatan tersebut sangat besar terutama untuk peningkatan kualitas sumberdaya manusia, baik dari sisi nelayan, stakeholders, maupun aparat penegak hukum, untuk mendukung upaya pemberantasan IUU fishing yang lebih efektif.

4. Peningkatan sarana dan prasarana terutama di bidang telekomunikasi, teknologi jarak jauh serta penguatan armada perikanan Indonesia untuk menanggulangi IUU fishing serta ditujukan untuk mendukung upaya konservasi dan pengelolaan perikanan yang bertanggung jawab.

Kemudian, upaya penegakan hukum untuk mewujudkan pengelolaan perikanan yang bertanggung jawab sebagaimana diamanatkan oleh ketentuanketentuan hukum internasional yang dicerminkan oleh Indonesia kedalam UndangUndang Nomor 45 tahun 2009 tentang Perikanan yakni dengan menyelenggarakan pengawasan perikanan. ${ }^{23}$ Bagi suatu negara sangatlah penting bagi pemerintahannya untuk melakukan penegakan hukum sebagai bentuk penerapan atas yurisdiksi dari suatu wilayah kedaulatan dan/atau hak berdaulat yang dimiliki negara tersebut.

20 Pasal 36 ayat (1) Undang-Undang Nomor 45 tahun 2009 tentang Perikanan.

21 Surat Izin Usaha Perikanan, yang selanjutnya disebut SIUP, adalah izin tertulis yang harus dimiliki perusahaan perikanan untuk melakukan usaha perikanan dengan menggunakan saran produksi yang tercantum dalam izin tersebut.

22 Pasal 26 ayat (2) Undang-Undang Nomor 45 tahun 2009 tentang Perikanan.

${ }^{23}$ Bab XII tentang Pengawasan Perikanan Pasal 66-70 Undang-Undang Nomor 45 tahun 2009 tentang Perikanan. 
Berbeda dengan di darat, penegakan hukum di laut menurut UNCLOS 1982 terbagi menjadi dua kategori. Pertama penegakan hukum di laut dibawah yurisdiksi kedaulatan negara pantai (Coastal State) seperti perairan dalam dan laut territorial atau perairan kepulauan dan laut territorial. Kedua penegakan hukum di laut yang berada dibawah yurisdiksi hak berdaulat negara yang diberikan oleh konvensi seperti Zona Ekonomi Eksklusif dan Landasan Kontinen. ${ }^{24}$ Hal ini yang menjadi perhatian khusus adalah pembagian yurisdiksi dalam penegakan hukum di laut terbagi menjadi dua yaitu kedaulatan dan hak berdaulat. Menurut Mochtar Kusumaatmadja penegakan hukum di laut terutama di Zona Ekonomi Eksklusif merupakan aspek yang sangat penting, karena tidak ada artinya jika memiliki hak berdaulat di Zona Ekonomi Eksklusif namun tidak dapat melakukan penegakan hukum atas hak berdaulat tersebut. $^{25}$

Republik Indonesia memiliki hak bedaulat di zona ekonomi eksklusif yang meliputi kegiatan-kegiatan untuk melakukan eksplorasi dan eksploitasi, serta konservasi dan pengelolaan pada sumber kekayaan alam hayati yang salah satunya yaitu sumber daya perikanan. Pada Zona Ekonomi Eksklusif Indonesia, apabila terjadi pelanggaran terhadap Peraturan Perundang-undangan yang telah tetapkan Zona Ekonomi Eksklusif Indonesia dalam pemanfaatan serta pengelolaan sumber daya maka berdasarkan Pasal 73 UNCLOS 1982 Republik Indonesia dapat melakukan upaya penegakan hukum.

Pada tanggal 19 dan 24 Desember 2019 tercatat terdapat setidaknya 63 kapalkapal penangkap ikan asing yang berasal dari Republik Rakyat Tiongkok dengan pengawalan dari China Coast Guard masuk ke dalam wilayah Zona Ekonomi Eksklusif Indonesia di Laut Natuna Utara. ${ }^{26}$ Pihak Badan Keamanan Laut (BAKAMLA) mengklaim telah melakukan penghadangan, dan menyatakan kapalkapal penangkap ikan asing yang berasal dari Republik Rakyat Tiongkok yang masuk ke dalam wilayah Zona Ekonomi Eksklusif Indonesia di Laut Natuna Utara dan telah melanggar wilayah Zona Ekonomi Eksklusif Indonesia dengan melakukan kegiatan Illegal, Unreported, and Unregulated (IUU) Fishing. Berdasarkan ketentuan peraturan perundang-undangan yang ada di Republik Indonesia, setiap kapal-kapal Fishing Fleet asing atau lokal yang memasuki wilayah Zona Ekonomi Eksklusif Indonesia untuk melakukan penangkapan wajib memiliki izin terlebih dahulu dari

${ }^{24}$ Kresno Buntoro, “Kegiatan Militer Di Zee Dan Pelaksanaan Hot Pursuit Di Indonesia” 12 (2013): Hlm. 50.

${ }^{25}$ Mochtar Kusumaatmadja, "Beberapa Permasalahan Pokok Sekitar Pengumuman Pemerintah Ri Tentang Zona Ekonomi Eksklusif Indonesia," Jurnal Hukum \& Pembangunan 10, No. 4 (August 2, 1980): Hlm. 389, Https://Doi.Org/10.21143/Jhp.Vol10.No4.821.

26 "Indo-Pacific News Di Twitter," Twitter, Accessed September 27, 2020, Https://Twitter.Com/Indopac_Info/Status/1211852199870918656. 
Pemerintah Republik Indonesia dengan harus terlebih dahulu memiliki dan membawa Surat Izin Penangkapan Ikan (SIPI). ${ }^{27}$

Dalam melakukan penegakan hukum di Zona Ekonomi Eksklusif Indonesia, Pemerintah Republik Indonesia telah menetapkan Undang-undang Nomor 5 Tahun 1983 tentang Zona Ekonomi Eksklusif Indonesia. Bedasarkan Pasal 13 Undangundang Nomor 5 Tahun 1983 tentang Zona Ekonomi Eksklusif Indonesia dalam rangka melaksanakan hak berdaulat, aparatur penegak hukum Republik Indonesia yang berwenang, dapat mengambil tindakan-tindakan Penegakan Hukum sesuai dengan Undang-undang Nomor 8 Tahun 1981 tentang Kitab Undang-undang Hukum Acara Pidana, dengan pengecualian sebagai berikut $:^{28}$

1. Penangkapan terhadap kapal dan/atau orang-orang yang diduga melakukan pelanggaran di Zona Ekonomi Eksklusif Indonesia meliputi tindakan penghentian kapal sampai dengan diserahkannya kapal dan/atau orang-orang tersebut dipelabuhan dimana perkara tersebut dapat diproses lebih lanjut

2. Penyerahan kapal dan/atau orang-orang tersebut harus dilakukan secepat mungkin dan tidak boleh melebihi jangka waktu 7 (tujuh) hari, kecuali apabila terdapat keadaan force majeure.

3. Untuk kepentingan penahanan, tindak pidana yang diatur dalam Pasal 16 dan Pasal 17 termasuk dalam golongan tindak pidana sebagaimana dimaksud dalam Pasal 21 ayat (4) huruf b Undang-undang Nomor 8 Tahun 1981 tentang Kitab Undang-undang Hukum Acara Pidana, dimana yang dimaksud dalam tindak pidana yang diatur dalam Pasal 16 dan Pasal 17 meliputi kegiatan-kegiatan yang berupa :

a. Kegiatan-kegiatan Eksplorasi dan Eksploitasi ekonomis seperti pembangkitan tenaga dari air, arus dan angin di Zona Ekonomi Eksklusif Indonesia yang tidak memiliki izin dari Pemerintah Republik Indonesia atau berdasarkan persetujuan internasional dengan Pemerintah Republik Indonesia. $^{29}$

b. Kegiatan-kegiatan pemanfaatan pulau-pulau buatan atau instalasi-instalasi atau bangunan-bangunan lainnya di Zona Ekonomi Eksklusif Indonesia yang tidak memiliki izin dari Pemerintah Republik Indonesia. ${ }^{30}$

c. Kegiatan-kegiatan penelitian ilmiah di Zona Ekonomi Eksklusif Indonesia yang tidak memiliki izin dari Pemerintah Republik Indonesia. ${ }^{31}$

Dalam Undang-undang Nomor 5 Tahun 1983 tentang Zona Ekonomi Eksklusif Indonesia aparatur Penegak Hukum yang diberikan kewenangan Penyidikan dalam

${ }^{27}$ Pasal 27 Undang-Undang Nomor 45 Tahun 2009 Tentang Perubahan Atas Undang-Undang Nomor 31 Tahun 2004 Tentang Perikanan

${ }^{28}$ Pasal 13 Undang-Undang Nomor 5 Tahun 1983 Tentang Zona Ekonomi Eksklusif Indonesia.

${ }^{29}$ Ibid., Pasal 5 Ayat 1

${ }^{30}$ Ibid., Pasal 6

${ }^{31}$ Ibid., Pasal 7 
Penegakan Hukum di Zona Ekonomi Eksklusif Indonesia adalah Perwira Tentara Nasional Indonesia Angkatan Laut yang ditunjuk oleh Panglima Angkatan Bersenjata Republik Indonesia. ${ }^{32}$ Namun terkait dengan tindak pidana yang berhubungan dengan bidang Perikanan, kewenangan Penyidikan dalam Penegakan Hukum di Zona Ekonomi Eksklusif Indonesia selain Perwira Tentara Nasional Indonesia Angkatan Laut dapat juga dilakukan oleh Penyidik Pegawai Negeri Sipil Perikanan, dan Pejabat Polisi Negara Republik Indonesia. ${ }^{33}$

Dalam penegakan hukum di laut juga terdapat Badan Keamanan Laut (BAKAMLA) ${ }^{34}$ Dalam melaksanakan tugas dan fungsinya Badan Keamanan Laut (BAKAMLA) memiliki kewenangan yang dilaksanakan secara terintegrasi dan terpadu dalam satu kesatuan komando dan kendali. Kewenangan tersebut meliputi : ${ }^{35}$

a. melakukan pengejaran seketika

b. memberhentikan, memeriksa, menangkap, membawa, dan menyerahkan kapal ke instansi terkait yang berwenang untuk pelaksanaan proses hukum lebih lanjut

c. mengintegrasikan sistem informasi keamanan dan keselamatan di wilayah perairan Indonesia danwilayah yurisdiksi Indonesia

Penuntutan tindak pidana Perikanan di Zona Ekonomi Eksklusif Indonesia dilakukan oleh Jaksa Penuntut Umum yang ditetapkan oleh Jaksa Agung. ${ }^{36}$ Pengadilan yang berwenang mengadili pelanggaran di Zona Ekonomi Eksklusif adalah pengadilan negeri yang daerah hukumnya meliputi pelabuhan dimana dilakukan penahanan terhadap kapal atau orang-orang yang melakukan pelanggaran di Zona Ekonomi Eksklusif. ${ }^{37}$ Dalam tindak pidana Perikanan Pemerintah Republik Indonesia membentuk Pengandilan Perikanan yang dibentuk di Negeri Jakarta Utara, Medan, Pontianak, Bitung, dan Tual. ${ }^{38}$ Penegakan hukum yang tegas di wilayah pengelolaan perikanan harus dilakukan terutama dikarenakan Indonesia yang terletak pada posisi geografis strategis.

\section{Langkah-langkah yang dapat Dilakukan oleh Pemerintah Republik Indonesia Dalam Melindungi Hak Berdaulat di Zona Ekonomi Eksklusif dari Tindakan Illegal, Unreported, and Unregulated (IUU) Fishing.}

Pemerintah Republik Indonesia memiliki Hak Berdaulat di Zona Ekonomi Eksklusif berupa kegiatan-kegiatan terkait Eksplorasi Eksploitasi serta Konservasi sumber daya alam baik hayati maupun non-hayati, termasuk juga terkait dengan

\footnotetext{
${ }^{32}$ Ibid., Pasal 14 Ayat 1

${ }^{33}$ Pasal 73 Ayat 1 Undang-Undang Nomor 31 Tahun 2004 Tentang Perikanan.

${ }^{34}$ Pasal 59 Ayat 3 Undang-Undang Nomor 32 Tahun 2014 Tentang Kelautan

35 Ibid., Pasal 63

${ }^{36}$ Pasal 14 Ayat 2 Undang-Undang Nomor 5 Tahun 1983 Tentang Zona Ekonomi Eksklusif Indonesia Jo Pasal 75 Ayat 1 Undang-Undang Nomor 45 Tahun 2009 Tentang Perubahan Atas Undang-Undang Nomor 31 Tahun 2004 Tentang Perikanan

${ }^{37}$ Pasal 14 Ayat 3 Undang-Undang Nomor 5 Tahun 1983 Tentang Zona Ekonomi Eksklusif Indonesia

${ }^{38}$ Pasal 71 Ayat 3 Undang-Undang Nomor 45 Tahun 2009 Tentang Perubahan Atas Undang-Undang Nomor 31 Tahun 2004 Tentang Perikanan
} 
kegiatan-kegiatan penelitian dan pemanfaatan pulau-pulau buatan. Dalam melindungi Melindungi Hak Berdaulat di Zona Ekonomi Eksklusif dari tindakan Illegal, Unreported, and Unregulated (IUU) Fishing, Pemerintah Republik Indonesia melakukan upaya Penegakan Hukum. Dalam Penegakan Hukum di laut yang dilakukan oleh Pemerintah Republik Indonesia telah ditemukan beberapa hambatan, antara lain :

a. Luas wilayah Penegakan Hukum di laut

b. Tata kelola Keamanan Laut (KAMLA)

c. Perjanjian batas di Zona Ekonomi Eksklusif

d. Pemanfaatan sumber daya di laut

Berdasarkan identifikasi 4 hambatan penegakan hukum di laut dapat dijelaskan masalah dalam penegakan hukum dilaut. Pertama, luas wilayah laut Republik Indonesia dimana total luas sekitar 7,8 juta $\mathrm{km}^{2}$ menyebabkan kapal patroli yang ada tidak dapat melakukan pengawasan secara efektif di seluruh wilayah laut Republik Indonesia. ${ }^{39}$ Hal ini diperparah dengan kurang optimalnya kapasitas dan kapabilitas sumber daya di lingkungan Kementerian/Lembaga yang memiliki kewenangan Penegakan Hukum di laut. Kedua, dalam Tata kelola Keamanan Laut (KAMLA) terdapat tumpang tindih kewenangan antara Kementerian/Lembaga Penegakan Hukum di laut. Tercatat terdapat 6 Kementerian/Lembaga Penegakan Hukum di laut yang armada patrol. ${ }^{40}$ Ketiga, belum adanya kepastian batas Zona Ekonomi Eksklusif melalui Perjanjian Internasional dengan negara tetangga menjadi penghambat Penegakan Hukum di laut. Berdasarkan 9 negara yang Zona Ekonomi Eksklusifnya berbatasan dengan Republik Indonesia dibutuhkan 22 perjanjian dan baru 11 perjanjian yang diselesaikan. ${ }^{41}$ Keempat, terkait pemanfaatan sumber daya di laut masih banyak nelayan-nelayan lokal yang belum mampu mengelola sumber daya hingga Zona Ekonomi Eksklusif dan hanya melakukan penangkapan ikan untuk kebutuhan sehari-hari. ${ }^{42}$

Dari penjelasan-penjelasan atas identifikasi 4 hambatan Penegakan Hukum di laut tersebut terdapat beberapa upaya yang dapat dilakukan oleh Pemerintah Republik Indonesia anatara lain :43

\footnotetext{
${ }^{39}$ Dirhamsyah, “Penegakan Hukum Laut Di Indonesia,” Pusat Penelitian Oseanografi Lipi, No. Maritime Law Enforcement (2007): Hlm. 8.

${ }^{40}$ Indonesia Ocean Justice Initiative, Materi Webinar "Penguatan Sistem Keamanan Laut Di Indonesia", Laksamana Madya Tni Aan Kurnia, S.Sos., M.M.

${ }^{41}$ Webinar Csop: Kompleksitas Hukum Terkait Penegakan Hukum Di Perairan Perbatasan, Bebeb Abdul Kurnia Nugraha Djundjunan, SH.,LLM.

${ }^{42}$ Indonesia Ocean Justice Initiative, Materi Webinar "Tantangan Indonesia Untuk Mengakhiri Praktik Illegal Fishing”, Laksamana Madya Tni Aan Kurnia, S.Sos., M.M.

43 "Policy Brief Ioji Tentang Penguatan Keamanan Laut Natuna Utara Untuk Menjaga Hak Berdaulat Indonesia," Accessed November 26, 2020, Https://Oceanjusticeinitiative.Org/WpContent/Uploads/2020/06/Kertas-Posisi-Ioji-Laut-Natuna-Utara-4-Min.Pdf.
} 
a. Seluruh Kementerian/Lembaga Penegakan Hukum di laut perlu bersinergi dan melaksanakan koordinasi patroli agar kehadiran kapal perang dan/atau kapal resmi pemerintah dapat berlangsung secara terus menerus.

b. Perlu dilakukan pertukaran data dan informasi khususnya informasi mengenai deteksi kapal ikan asing baik dalam bentuk citra satelit, deteksi transmitter AIS/VMS, deteksi radar, dan lain-lain secara terus menerus dan berkelanjutan.

c. Pengadilan perlu menjatuhkan sanksi yang menjerakan kepada kapal asing pelaku IUU fishing termasuk menjatuhkan hukuman pemusnahan kapal.

d. Menyusun Peraturan Perundang-undangan tentang Keamanan Laut (KAMLA) yang disertai dengan pembentukan Coast Guard Unit ${ }^{44}$ yang bersifat Single Agency Multy Tasks ${ }^{45}$ untuk menguatkan koordinasi antar Kementerian/Lembaga Penegakan Hukum di laut, dan menjadi solusi tumpang tindih kewenangan antar Kementerian/Lembaga Penegakan Hukum di laut.

e. Meningkatkan Intensifikasi nelayan Republik Indonesia di Zona Ekonomi Eksklusif.

f. Membentukan koperasi nelayan dan bantuan modal untuk pengadaan kapal penangkap ikan dengan ukuran besar 100 - 150 GT sehingga dapat melakukan penangkapan ikan sampai batas terluar Zona Ekonomi Eksklusif Indonesia.

g. Memperdayakan nelayan-nelayan untuk membantu mengumpulkan informasi mengenai keberadaan kapal asing khususnya di wilayah batas terluar Zona Ekonomi Eksklusif Indonesia.

h. Membuat Perjanjian Internasional mengenai mekanisme kerjasama Penegakan Hukum di Zona Ekonomi Eksklusif yang masih bersengketa dengan negara tetangga, dan

i. Segera menegaskan kembali dan menyelesaikan perjanjian batas Zona Ekonomi Eksklusif.

\section{PENUTUP}

Berdasarkan hasil pembahasan, dapat disimpulkan bahwa ada beberapa hal yang dapat dilakukan oleh pemerintah Republik Indonesia sebagai bentuk upaya penanggulangan IUU Fishing di wilayah ZEEI dari Kapal Penangkap Ikan Asing. Upaya penanggulangan tersebut yaitu melalui cara pentaatan hukum dan penegakan hukum yang tegas. Pemerintah Republik Indonesia dapat melakukan penegakan hukum sebagaimana diberikannya kewenangan untuk mengelola ZEE yang diberikan oleh Hukum Internasional melalui UNCLOS 1982. Upaya yang dapat Dilakukan oleh Pemerintah Republik Indonesia Dalam Melindungi Hak Berdaulat di Zona Ekonomi Eksklusif dari Tindakan Illegal, Unreported, and Unregulated (IUU) Fishing adalah meningkatkan koordinasi patrol Penegakan Hukum di laut, memperdayakan nelayan

${ }^{44}$ Op. Cit. Dirhamsyah, Hlm. 10

${ }^{45}$ Eka Martiana Wulansari, "Penegakan Hukum Di Laut Dengan Sistem Single Agency Multy Tasks," N.D., Hlm. 4-6. 
lokal untuk meningkatkan Intensifikasi nelayan Republik Indonesia di Zona Ekonomi Eksklusif, membentuk Coast Guard Unit, dan menyelesaikan perjanjian batas Zona Ekonomi Eksklusif.

\section{DAFTAR PUSTAKA}

Ana Fatmawati, Elsa Aprina, Keabsahan Alasan Penolakan Republik Rakyat Tiongkok Terhadap Putusan Permanent Court Arbitration Atas Sengketa Klaim Wilayah Laut China Selatan Antara Filipina dan Republik Rakyat Tiongkok, Jurnal Varietas Justisia Volume 5 Nomor 1

Buntoro, Kresno. “KEGIATAN MILITER DI ZEE DAN PELAKSANAAN HOT PURSUIT DI INDONESIA" 12 (2013): 19.

Callista, Prameshwari Ratna, Muchsin Idris, And Nanik Trihastuti. "KLAIM TIONGKOK TENTANG TRADITIONAL FISHING GROUND DI PERAIRAN NATUNA INDONESIA DALAM PERSPEKTIF UNCLOS 1982" 6 (2017): 13.

Cornelis Djelfie Massie. PENGANTAR HUKUM KAWASAN PERBATASAN DAN PULAUPULAU TERLUAR INDONESIA Perspektif Hukum Laut Internasional. I. Pustaka Referensi, 2019.

Darajati, Muhammad Rafi, Huala Adolf, And Idris Idris. "PUTUSAN SENGKETA LAUT CHINA SELATAN SERTA IMPLIKASI HUKUMNYA TERHADAP NEGARA DI SEKITAR KAWASAN TERSEBUT." Jurnal Hukum \& Pembangunan 48, No. 1 (April 17, 2018): 22-43. Https://Doi.Org/10.21143/.Vol48.No1.1594.

Dhiana Puspitawati. HUKUM LAUT INTERNASIONAL. Pertama. Depok: Kencana, 2017.

Dirhamsyah. "PENEGAKAN HUKUM LAUT DI INDONESIA." Pusat Penelitian Oseanografi LIPI, No. Maritime Law Enforcement (2007): 13.

"Illegal, Unreported And Unregulated (IUU) Fishing | Food And Agriculture Organization Of The United Nations." Accessed February 1, 2020. Http://Www.Fao.Org/Iuu-Fishing/En/.

Twitter. "Indo-Pacific News Di Twitter." Accessed September 27, 2020. Https://Twitter.Com/Indopac_Info/Status/1211852199870918656.

J. Supranto. METODE PENELITIAN HUKUM DAN STATISTIK. Pertama. Jakarta: Rineka Cipta, 2003.

Junef, Muhar. "Sengketa Wilayah Maritim Di Laut Tiongkok Selatan." Jurnal Penelitian Hukum De Jure 18, No. 2 (June 26, 2018): 219-40. Https://Doi.Org/10.30641/Dejure.2018.V18.219-240.

Kusumaatmadja, Mochtar. "BEBERAPA PERMASALAHAN POKOK SEKITAR PENGUMUMAN PEMERINTAH RI TENTANG ZONA EKONOMI EKSKLUSIF INDONESIA.” Jurnal Hukum \& Pembangunan 10, No. 4 (August 2, 1980): 384-89. Https://Doi.Org/10.21143/Jhp.Vol10.No4.821.

Media, Kompas Cyber. "Masuknya Kapal China Ke Perairan Natuna Yang Diprotes Indonesia... Halaman All.” KOMPAS.Com. Accessed January 4, 2020. Https:/Www.Kompas.Com/Tren/Read/2019/12/31/164819565/MasuknyaKapal-China-Ke-Perairan-Natuna-Yang-Diprotes-Indonesia. 
ISSN (Print): 2085-8477; ISSN (Online): 2655-4348

Garis pantai Indonesia terpanjang kedua di dunia, diakses melalui

https://www.antaranews.com/berita/487732/garis-pantai-indonesia-terpanjang-kedua-di-dunia

PCA Press Release: The South China Sea Arbitration (The Republic Of The Philippines V. The People's Republic Of China) | PCA-CPA. Accessed November 15, 2020.

Peter Mahmud Marzuki. PENELITIAN HUKUM. Pertama. Jakarta: Kencana Prenada Media Group, 2009.

"Policy Brief IOJI Tentang Penguatan Keamanan Laut Natuna Utara Untuk Menjaga Hak Berdaulat Indonesia." Accessed November 26, 2020. Https://Oceanjusticeinitiative.Org/Wp-Content/Uploads/2020/06/KERTASPOSISI-IOJI-LAUT-NATUNA-UTARA-4-Min.Pdf.

Salle, S. Sistem Hukum Dan Penegakan Hukum. CV. Social Politic Genius (Sign), 2020.

Sodik, Dikdik Mohamad. Hukum Laut Internasional Dan Pengaturannya Di Indonesia, 2014. Sulistyanto, Joko. "IMPLEMENTASI KONVENSI HUKUM LAUT INTERNASIONAL 1982 DALAM PEMBAHARUAN UNDANG-UNDANG PERIKANAN." Jurnal Lex Librum 1, No. Nomor 1 (December 8, 2014): 35-43. Https://Doi.Org/10.5281/Zenodo.1256373.

UNCLOS And Agreement On Part XI - Preamble And Frame Index. Accessed January 28, 2020.

Https:/Www.Un.Org/Depts/Los/Convention_Agreements/Texts/Unclos/Cl osindx.Htm.

Undang-undang Nomor 5 Tahun 1983 Tentang Zona Ekonomi Eksklusif Indonesia. Accessed October 21, 2020. Http://Www.Dpr.Go.Id/Jdih/Index/Id/781.

Undang-undang Nomor 31 Tahun 2004 Tentang Perikanan.

Undang-undang Nomor 45 Tahun 2009 Tentang Perubahan Atas Undang-Undang Nomor 31 Tahun 2004 Tentang Perikanan.

Undang-undang Nomor 8 Tahun 1981 Kitab Undang Undang Hukum Acara Pidana.

Wang, Zheng. "China And UNCLOS: An Inconvenient History." Accessed November 12, $2020 . \quad$ Https://Thediplomat.Com/2016/07/China-And-Unclos-AnInconvenient-History/.

Wulansari, Eka Martiana. "PENEGAKAN HUKUM DI LAUT DENGAN SISTEM SINGLE AGENCY MULTY TASKS,” N.D., 6. 